\section{Um sonbo imperial: Constantino e a invenção do cristianismo}

Paul VEYNE. Quando nosso mundo se tornou cristão (312-394). Rio de Janeiro, Civilização Brazileira, 2010. 288 páginas

\section{Breno Rodrigo de Oliveira Alencar}

É impossível ficarmos indiferentes diante dos livros de Paul Veyne. Eles geralmente têm o efeito de estímulo intelectual, quer por quem partilha ou não suas ideias. O grande mérito deste autor está na sua capacidade em apresentar um tema de maneira que um especialista no mundo romano antigo e um leigo no assunto possam debatê-lo. Em uma época de hiperespecialização, preocupar-se em se tornar compreensível, ou mesmo tornar sua disciplina atrativa, é uma qualidade rara o suficiente para ser sublinhada. Por essa razão o leitor não ficará desapontado. $\mathrm{O}$ estudioso encontrará pontos de vista que pode convidá-lo para qualificar o seu, e ao neófito será oferecido um percurso cronológico e religioso esclarecedor sobre um tema tão complexo que Veyne escolheu para enfrentar: nada menos do que a conversão de Constantino, episódio que abriu caminho para o advento do cristianismo.

Cronologicamente o texto inicia-se e conclui-se com duas batalhas: a primeira, e mais famosa, é a de Ponte Mílvio (ou Mílvia), perto de Roma, onde Constantino elimina seu rival Maxêncio, em 28 de outubro de 312. Esta vitória, que ele atribuiu à proteção do Deus cristão, é o ponto de partida de sua conversão ao cristianismo. A segunda batalha, quase desconhecida do público em geral, é a do Rio Frio (ou Vipacco, em italiano, na fronteira entre a autal Itália e a Eslovênia), onde Teodósio, imperador cristão de Constantinopla, venceu, em 6 de setembro de 394, Flavius Eugenius, ou "O Usurpador", que havia tomado o poder no Ocidente. Este último, enquanto fora cristão, havia sido tolerante com os pagãos, especialmente os de Roma.

Estas duas batalhas foram em si apenas epifenômenos políticos e militares que permitiram a dois indivíduos ambiciosos impor ou permanecer à frente do Império. Mas estas duas "cabeças quentes" também eram igualmente influenciadas por crenças religiosas, cuja análise de Veyne aponta contribui- ções que alteraram a face do mundo romano. Com efeito, é a partir de 312 que Constantino afirmou-se, e cada vez mais, como cristão. É a partir de 392 (com a lei que proibiu os ritos pagãos, pública ou privativamente) e mais ainda em 394 (ano do fim "da reação pagã tolerada por Eugenius) que o cristianismo se tornou a religião oficial. Portanto, conclui Veyne, trata-se de um conflito pelo trono que deu ensejo a uma revolução religiosa - ao contrário do que se pensa -, no qual a proibição do paganismo seria o resultado de um conflito político.

Metade da obra é consagrada à conversão de Constantino, fato que encerra definitivamente a Era das perseguições. Mas sobre este assunto, crê-se que tudo já foi dito (ou quase tudo), uma vez que muita tinta se usou para descrever Constantino como um personagem calculista, frio; um oportunista que tomou conhecimento da falha de perseguição; um idólatra sincrético do culto a Apolo; ou um pagão que raramente era sincero com o cristianismo. Veyne, por outro lado, tenta nos convencer que essa é uma visão equivocada e procura defender a opinião de que Constantino pegou carona nos acontecimentos da época.

No livro Histoire du christianisme, dedicado à conversão de Constantino, Charle Pietri contornou cuidadosamente o problema, tomando cuidado para não favorecer nenhuma abordagem específica. "O episódio da Ponte Mílvio", escreveu ele, "importa muito pouco em si mesmo: o que importa é a roupagem que o príncipe queria dar-lhe para mostrar a sua epifania brilhante através de um compromisso cristão" (Pietri, 1995, p. 196). Veyne não hesitou, por seu lado, em retomar este assunto que dificulta o historiador obstinado: ele aborda as origens de sua conversão em dois capítulos que apresentam títulos significativos: "Uma obra-prima: o cristianismo" (capítulo 2) e "Outra obra-prima: a Igreja" (capítulo 3). Ao fazer isso, enumera os elementos que conferiam a superioridade do cristianismo em relação ao paganismo, assim como influenciaram na escolha de Constantino: uma religião de amor (p. 37), a profissão de fé (pp. 63, 87 e 125), a defesa de uma concepção sublime do mundo e do homem (p. 38), a qual, por intermédio da figura de seu fundador, um personagem histórico datado, demonstra- 
va um zelo moralizador (p. 43). Veyne, contudo, expressa suas reservas quanto ao papel que poderiam desempenhar uma promessa de imortalidade da alma e a perspectiva da ressurreição dos corpos, bem como o seu corolário: o medo do inferno.

Esses capítulos têm o grande mérito de sublinhar a extrema originalidade e a incontestável audácia da proposta cristã, que o autor não se detém em admirar: "o cristianismo era também uma crença, uma espiritualidade, uma moral e uma metafísica, tudo sob uma autoridade eclesial. Ele ocupou todo o espaço [...]. E se distinguia por ser a única religião no mundo que também era uma Igreja” (pp. 64-72).

Pode-se, no entanto, contestar algumas de suas afirmações relativas à natureza do cristianismo, que ele considera um "um politeísmo monista” (p. 40), assim como sua visão global da nova religião, resultado de uma "inventividade religiosa" ou "uma invenção coletiva de gênio" (p. 41) que asseguraram-lhe um sucesso digno de best-seller (as expressōes são repetidas em várias ocasiōes).

Após descrever como o cristianismo despontou no intervalo entre os séculos III e IV, Veyne expõe a sua compreensão da conversão de Constantino. Ele, no entanto, não procura desvendar os motivos do imperador, que, em suas próprias palavras, “são impenetráveis, estão na 'caixa preta' impossível de abrir de que falam os psicólogos” (p. 104). Constantino foi, na sua opinião, um crente sincero, habitado pela convicção de ser o receptor afortunado de uma graça providencial que lhe permitiu restaurar a unidade do Império. Com isso em mente, Veyne retoma o sonho que o imperador havia tido na véspera da Batalha da Ponte Mílvio, em que previu sua vitória, com o objetivo de desmistificá-lo. Segundo ele, o imperador não age por um fim calculista, apesar de reconhecer que Constantino estava inteirado dos benefícios políticos que poderia adquirir com essa conversão.

Com ênfase na boa-fé de Constantino, o livro de Veyne presta uma grande contribuição a uma abordagem até então ignorada, convidando o leitor a revisar sua opinião sobre este imperador. Para ele, Constantino foi um príncipe cristão de uma astúcia excepcional, que tinha em mente um projeto maior, mesclando piedade e poder: cons- truir uma sociedade cristã e, por conseguinte, um império político e religioso. Projeto abrangente que foi, afinal, apenas parcialmente bem-sucedido, uma vez que após sua morte, no ano de 337 , a Igreja foi duplamente afetada pela heresia (do arianismo no Oriente) e por um cisma (o donatismo na África); a unidade política do Império não poderia sobreviver sem restauração.

A sequência da obra analisa a evolução das relaçôes entre paganismo e cristianismo a partir de 312. Nesse sentido, Constantino conserva sua qualidade de grande pontífice em Roma, oferecendo a si próprio um arco, que simboliza sua vitória como instinctu divinitatis. Trata-se de uma fórmula na qual, de um modo original, Veyne enxerga não um gesto de neutralidade para com os pagãos, mas a expressão de uma reserva pagã em relação a um evento dentro da privacidade imperial. Por essa razão, após sua morte foi declarado Divus pelos pagãos, o que, de fato, enfraquecia perigosamente a função imperial e sua convicção religiosa.

Ciente deste perigo, Constantino favoreceu politicamente a Igreja cristã de múltiplas maneiras (dons, instauração do Domingo, reconhecimento da audientia episcopalis...) sem, no entanto, erradicar as superstições antigas. Sobre este ponto, no entanto, Veyne não é totalmente claro. Ele considera Constantino o presidente da Igreja que renunciará a converter as mentes pecadoras e erradicar o paganismo, muito embora sua grande intenção fosse ampliar concretamente o triunfo místico de Cristo e pôr termo ao reino dos falsos deuses. Veyne ainda insiste no fato de que Constantino tentou "erradicar a adoração de demônios e abolir o rito da adoração e principalmente o sacrifício de animais e de sangue" (p. 171). Por outro lado, o autor tenta livrar-se de tal impasse afirmando que, até cerca do ano de 390, o paganismo era parcialmente tolerado, praticamente suportado. Mas sejamos claros (se é que isso é possível): Veyne demonstra que o paganismo era cada vez menos estimado, e, diante da forte resistência pagã, foi necessário multiplicar e repetir as leis que proibiam os sacrifícios (noturnos e diurnos, públicos e privados).

Após as reações pagãs à época de Juliano e Eugenius, o golpe de misericórdia foi dado em 392, quando as autoridades fecharam seus olhos e ou- 
vidos para as sobrevivências do paganismo e reduziram seus adeptos à insignificância, chegando mesmo a ignorar sua cidadania (p. 174). Embora a queda do paganismo não tenha se dado de forma pacífica (houve episódios violentos), é necessário sublinhar que as diferenças religiosas não provocaram uma guerra civil ou religiosa. Pagãos e cristãos encontraram-se, de fato, sob a liderança (mais precisamente do cetro e da espada, com os quais eles não deveriam brincar) de um imperador que se tornou cristão e ao qual deveriam mostrar compromisso, por princípio e/ou de coração, e o orgulho de ser romano (sentimento ainda mais forte em tempos em que a Eternitas romana estava sendo ameaçada pelos bárbaros).

Os três últimos capítulos permitem ao autor alargar as perspectivas de sua investigação, demonstrando que data do reinado de Constantino o surgimento do antijudaísmo, que posteriormente se transformou em antissemitismo. Interessado principalmente no destino dos judeus do Império, Veyne considera que eles se beneficiaram de séculos de tolerância religiosa, mesmo diante da conversão de Constantino. Por um fato até então ignorado, esses judeus passaram a ser considerados os "falsos irmãos", uma vez que, diante da ascensão da nova fé, eram aqueles que adoravam o mesmo Deus que os cristãos, mas não reconheciam Jesus Cristo; este passo intransponível levou-os à evasão do Império para reafirmarem sua identidade, processo que começou, pode-se corrigir, desde a queda do Templo no ano de 70 . Veyne conclui que os judeus se tornaram no Império cristão o outro difícil de tolerar.

A penúltima consideração de Veyne diz respeito à conversão de Constantino: seria ela um ato de boa fé ou não passaria de uma investida ideológica com propósito puramente político? A segunda proposição corroboraria certamente a ideia de um Constantino calculista: "Se Constantino torna-se cristão é porque isso serve ao seu poder" (p. 231). Como vimos, Veyne contesta vigorosamente tal teoria, considerando que o poder imperial serviu mais à causa religiosa do que a ele propriamente (p. 212). Uma passagem, em particular, sugere-nos "acabar com o lugar-comum, segundo o qual a Europa devia ao cristianismo o fato de ter separado política e religião" (p. 218). Para Veyne, os pagãos já separavam o deus César da raça dos homens e da raça dos Deuses; uns e outros mantinham uma relação de tipo contratual. A mudança que se operou com o cristianismo residia no fato de que a mão de Deus começou a pesar sobre a cabeça do imperador, este último convidado a pôr-se ao serviço de Deus e a rendê-lo as honras devidas.

Certamente, na cidade antiga, entendem os pré-cristãos, que os deuses eram, sobretudo, os da cidade, e que deveriam ser tratados como divindades polias. Esta cidade é voluntariamente mostrada como o protótipo da comunidade inseparável, política e religiosamente. Quando Veyne arrisca-se afirmar que "a religião estava por toda parte, salpicava todas as coisas, mas era simples e ligeira, revestia todas as coisas de solenidade, sem criar grandes obrigaçōes” (p. 218), ele quer dizer que os ritos pagãos não estruturavam o indivíduo e a sociedade como o cristianismo foi capaz de fazer por meio de seu conteúdo dogmático. Como Veyne afirma no início do livro, "um pagão se contentava se seus deuses o socorressem em seus pedidos e seus desejos, mas um cristão queria antes um modo de fazer com que seu Deus ficasse contente com ele" (p. 18). Com a conversão de Constantino, uma nova Era surgiu, em que o imperador foi convidado, como diz Agostinho de Hipona (1992), "a pôr-se a serviço da majestade divina” (Cidade de Deus, confissões 5,24). $\mathrm{E}$, de fato, a ordem temporal esteve por vários séculos subordinada ao domínio sobrenatural.

O último ponto que Veyne desenvolve nos remete ao presente. $\mathrm{O}$ autor interroga-se, com efeito, se a Europa tem raízes cristãs (diga-se de passagem, este certamente não é um capítulo muito convincente). $\mathrm{O}$ autor inverte a perspectiva, afirmando que foi o cristianismo que se enraizou na Europa, e que ele não constitui uma de suas raízes, hoje ainda menos que ontem, tendo em conta "a configuração presente das coisas" (Montesquieu). Deixemos de lado a reviravolta. O que Veyne afirma não deixa de ser verdade, pois, como sublinha R. Brague (1992), o que faz a unidade da Europa são mais ou menos duas ou três tradiçôes representadas por três cidades: Atenas, Jerusalém e Roma.

Pode-se preferir também a recente análise de Manent (2006) a esse respeito: "Algo impede de dizer que a Europa não é cristã. Retornamos a Eu- 
ropa real que nos esforçamos em vão de deixar. Redescobrindo na paisagem familiar a promessa de comunhão contida na proposta cristã e implantando no Império cristão a Igreja romana, cada nação tem traduzido nos seus costumes e na sua língua uma apropriação cada vez mais íntima, até mesmo assimilando a Igreja na nação cristã, transformando a nação em Igreja” (pp. 95ss.). No que concerne a esta questão, lamentamos alguns pressupostos políticos e religiosos de Veyne, identificados ao longo do livro (pp. 47, 49, por exemplo), e cuja utilidade não se torna clara em sua conclusão.

No geral, podemos nos surpreender com a "descoberta" que Veyne parece ter feito sobre "as visōes do homem providencial" de Constantino, a quem ele chama de "herói" (p. 11); podemos sorrir da admiração que sente e que não procura dissimular para com este príncipe que não deixou o cristianismo se tornar uma simples seita de vanguarda; ou podemos nos irritar com certos vieses tomados pelo autor. Temos de reconhecer, contudo, que o grande mérito da obra foi o de ter reabilitado uma certa concepção da conversão de Constantino: a que enxerga neste acontecimento não o fruto de um cálculo ideológico, mas uma decisão sincera, tomada por um soberano que descobriu o papel que ele podia desempenhar no plano divino para a economia da salvação. Apesar disso, Veyne não faz de Constantino um santo, nem mesmo, a exemplo da Igreja Ortodoxa, o décimo terceiro apóstolo; sua conversão não significou uma ruptura radical e definitiva com o passado religioso de Roma. O imperador favoreceu, é claro, a Igreja cristã, mas soube conciliar seu projeto hegemônico com um paganismo ainda bem vivo. Estava ele, de fato, imbuído por um projeto profundamente audacioso: realizar sob sua autoridade a unidade política e religiosa do Império romano - apostando somente em ganhar.

\section{BIBLIOGRAFIA}

AgOSTINHO. (2002), A cidade de Deus. Petrópolis, Vozes.

BRAGUE, R. (1992), Europe, lavoieromaine. Paris, Critérion.
MANENT, P. (2006), La raison des nations: réflexions sur la démocratie en Europe. Paris, Gallimard.

PIETRI, C. \& PIETRI, L. (1995), "Naissance d'une chrétienté", in J. M. Mayeur et al. (eds.) (1995), Histoire du christianisme II: Naissance d'une chrétienté 250-430. Paris, Desclée.

\section{BRENO RODRIGO DE OLIVEIRA ALENCAR é mestre em Antropologia pelo PPGCS-UFPA e etnógrafo do Museu Paraense Emílio Goeldi. E-mail: <brodrigo@museu-goeldi.br>.}

